\title{
Effects of Cyclic Adenosine 3': 5'-Monophosphate on Phosphoprotein Kinase and Phosphatase Fractions Prepared from Rat Liver Nuclei
}

\author{
LINDA DOKAS, ${ }^{1}$ DANIEL RITTSCHOF ${ }^{2}$ AND LEWIS J. KLEINSMITH
}

\author{
Division of Biological Sciences, University of Michigan, Ann Arbor, Michigan 48109
}

Received September 19, 1977; revised July 14, 1978

\begin{abstract}
A soluble rat liver nuclear extract containing total RNA polymerase activities also exhibits appreciable amounts of protein kinase activity. This unfractionated protein kinase catalyzes the phosphorylation of both endogenous proteins and exogenous lysine-rich histone in the presence of $\left[\gamma^{32} \mathrm{P}\right] \mathrm{ATP}$ and $\mathrm{Mg}^{2+}$. The optimal concentration of $\mathrm{Mg}^{2+}$ is 5 $\mathrm{mM}$ for histone phosphorylation and $25 \mathrm{mM}$ for the phosphorylation of endogenous proteins. Cyclic AMP has no effect on the phosphorylation of lysine-rich histone by this unfractionated nuclear protein kinase. However, addition of cyclic AMP causes a reduction in the ${ }^{32} \mathrm{P}$ labeling of an endogenous protein (CAI) which can be characterized by its mobility during SDS-acrylamide gel electrophoresis and elution in the unbound fraction of a DEAESephadex column. If CAI is first labeled with ${ }^{32} \mathrm{P}$ and then incubated with $10^{-6} \mathrm{M}$ cyclic AMP under conditions where protein kinase activity is inhibited, the presence of the cyclic nucleotide causes a loss of the ${ }^{32} \mathrm{P}$-labeling of this protein, implying the activation of a substrate-specific protein phosphatase. When rat liver RNA polymerases are purified by DEAE-Sephadex chromatography, protein kinase activity is found in the unbound fraction and in those column fractions containing RNA polymerase I and II. The fractionated protein kinases exhibit different responses to cyclic AMP, the unbound protein kinase being stimulated and the RNA polymerase-associated protein kinases being dramatically inhibited. A second protein (CAII) whose phosphorylated state is modified by cyclic AMP is found within the DEAE-Sephadex column fractions containing RNA polymerase II. The cyclic nucleotide in this case appears to reduce labeling of CAII by inhibition of the protein kinase activity which co-chromatographs with both CAII and RNA polymerase II. Based on molecular weight estimates, neither CAI nor CAII appears to be an RNA polymerase subunit. The identity of CAI as a protein factor whose phosphorylated state influences nuclear RNA synthesis is suggested by the fact that addition of fractions containing CAI to purified RNA polymerase II inhibits the activity of this enzyme, but only if CAI has been previously incubated in the presence of cyclic AMP.
\end{abstract}

Models for regulation of transcription from eukaryotic chromatin have centered around two basic mechanisms. The first of these is based upon the knowledge that the class of small basic proteins termed histones serve as inhibitors of transcription (1, 2). Although as a group they lack tissue and species specificity (3), they must be included in any general scheme for nuclear genetic regulation, since they are the only

\footnotetext{
${ }^{1}$ Present address: University of Michigan, Neuroscience Laboratory Building, Ann Arbor, Michigan 48109. To whom all correspondence should be addressed.

${ }^{2}$ Present address: Department of Physiology, School of Medicine, University of California at Los Angeles, Los Angeles, California 90024.
}

major chromatin component shown to block transcription. On the other hand, the acidic nuclear proteins are heterogeneous (4), tissue-specific (5), and confer specificity on patterns of nuclear RNA synthesis (6, 7). These characteristics have led to the proposal that positive regulation of transcription from chromatin exists, based upon functional interaction of the acidic nuclear proteins with the other nuclear components, for example, RNA polymerase or repetitive DNA sequences (8). The structural and functional complexity of the nucleus does not preclude the possibility that both modes of regulation may occur simultaneously.

Complexes between nuclear acidic pro- 
teins and histones do exist $(9,10)$, and it is possible that this protein-protein interaction accounts for many of the properties of the regulation of RNA synthesis within the nucleus. Removal of the general inhibitory influence of the histones from chromatin by association with specific acidic proteins could unmask certain sequences of DNA for transcription. Once accomplished, the interaction of eukaryotic RNA polymerases with protein factors which modify their ability to synthesize RNA could constitute a secondary site for positive regulation of genetic activity. The coordinated regulation of protein-protein interactions of these two types (histone-acidic protein and RNA polymerase-protein factors) could provide a well-defined, stringent system to ensure the unique transcription of particular chromatin sites.

If so, some process must exist for altering the functional association of these proteins. Phosphorylation of nuclear proteins, primarily the nonhistones, correlates well with genetic activity $(11,12)$. Within the last few years, the involvement of nuclear protein phosphorylation as a factor in regulation has been seen to be increasingly complex. One aspect of this complexity is that cyclic AMP functions within the nucleus in a variety of ways to influence the state of nuclear protein phosphorylation. On the one hand, this nucleotide stimulates the phosphorylation of lysine-rich histone, presumably opening up new sites for transcription (13). In addition, cyclic AMP has also been shown to affect the phosphorylated state of the nonhistone proteins both in a positive and a negative manner (14-16). In most cases, it remains to be demonstrated clearly that these cyclic AMP-induced changes in phosphorylation are linked in a causal manner to the interaction, and hence, to the function of the nuclear proteins.

The present studies demonstrate the presence of protein kinase and protein phosphatase activity in a rat liver nuclear extract containing RNA polymerase activities. While studying the effects of cyclic AMP on these enzymes and upon the phosphorylated state of nuclear phosphoproteins, we have found that cyclic AMP causes: 1) inhibition of the protein kinases which co-chromatograph with both forms of RNA polymerase on a DEAE-Sephadex column and stimulation of a protein kinase which separates from these enzymes in the unbound fraction from this column, and 2) activation of a nuclear protein phosphatase which reduces the phosphorylation of a specific nonhistone protein (CAI), That CAI may function within the nucleus as a regulator of RNA polymerase activity is suggested by the fact that following preincubation with cyclic AMP, CAI is able to inhibit the activity of RNA polymerase II.

Preliminary reports of this work have already appeared $(4,17)$. This work suggests that cyclic AMP can influence the phosphorylation of nuclear proteins in such a manner as to modify the functional interactions of such proteins with other nuclear components, possibly including RNA polymerase.

\section{MATERIALS AND METHODS}

Preparation of a soluble rat liver nuclear extract. The procedure was the method of Roeder and Rutter for the preparation of liver RNA polymerases (18). For each preparation, $25 \mathrm{~g}$ of rat liver were homogenized in 2 volumes of $0.34 \mathrm{M}$ sucrose, $15 \mathrm{mM}$ magnesium acetate, $0.25 \mathrm{mM}$ spermine. The homogenate was diluted with 2 volumes of $2.3 \mathrm{M}$ sucrose; 28 -ml portions were placed in centrifuge tubes and underlayered with $10 \mathrm{ml}$ of $2.3 \mathrm{M}$ sucrose. After centrifugation at 105,000 $g$ for $1 \mathrm{hr}$, the nuclear pellets were suspended in $50 \mathrm{ml}$ of $0.01 \mathrm{M}$ Tris- $\mathrm{HCl}, \mathrm{pH} 7.9,1.0 \mathrm{M}$ sucrose, $5 \mathrm{mM} \mathrm{MgCl}_{2}$, $5 \mathrm{~mm}$ dithiothreitol. Ammonium sulfate (4 M) was added to a final concentration of $0.3 \mathrm{M}$ and the viscous solution stirred for $10 \mathrm{~min}$.

The preparation was sonicated in $25-\mathrm{ml}$ fractions for $10 \mathrm{~s}$ at setting 75 on a Biosonic sonicator (Bronwill) equipped with a microtip. The sonication was repeated 5 times with a 30 -s pause between each sonication. Two volumes of $0.05 \mathrm{M}$ Tris- $\mathrm{HCl}, \mathrm{pH} \mathrm{7.9,25 \%}$ glycerol, $5 \mathrm{mM} \mathrm{MgCl}_{2}, 0.1 \mathrm{mM}$ EDTA, $0.5 \mathrm{~mm}$ dithiothreitol were added. After mixing, the solution was centrifuged for $1 \mathrm{~h}$ at $105,000 \mathrm{~g}$. Solid ammonium sulfate was added to the supernatent over a period of $30 \mathrm{~min}$ and the solution stirred at $4^{\circ} \mathrm{C}$ for an additional $40 \mathrm{~min}$. After centrifugation at $105,000 \mathrm{~g}$ for $1 \mathrm{~h}$, the protein pellets were suspended in $\mathrm{TGMED}^{3}$ and dialyzed against TGMED, $0.05 \mathrm{M}$ ammonium sulfate for 4-6 $\mathrm{h}$. The pellets resulting from a centrifugation at 105,000 $g$ for $1 \mathrm{~h}$ were discarded and the supernatent assayed

${ }^{3}$ Abbreviations used: TGMED, 0.05 м Tris-HCl, pH 7.9, 25\% glycerol, $5 \mathrm{~mm} \mathrm{MgCl}_{2}, 0.1 \mathrm{~mm}$ EDTA, and $0.5 \mathrm{~mm}$ dithiothreitol; TCA, trichloroacetic acid; SDS, sodium dodecyl sulfate; CAI and CAII, cyclic AMPinfluenced protein I and protein II. 
for RNA polymerase activity. The enzyme was stored at $-76^{\circ} \mathrm{C}$ in TGMED, $0.05 \mathrm{M}$ ammonium sulfate.

Assay of RNA polymerase activity. The assay for RNA polymerase activity contained the following in a final reaction volume of $0.75 \mathrm{ml}: 60 \mathrm{mM}$ Tris- $\mathrm{HCl}, \mathrm{pH}$ $8.0,3 \mathrm{~mm} \mathrm{NaF}, 20 \mathrm{~mm} \mathrm{MgCl}_{2}, 3 \mathrm{~mm}$ spermine, $0.4 \mathrm{M}$ ATP, CTP, and GTP, $100 \mu \mathrm{g}$ of calf thymus DNA in $0.1 \times \mathrm{SSC}(0.015 \mathrm{M} \mathrm{NaCl}, 0.0015 \mathrm{M}$ sodium citrate) and $1 \mu \mathrm{Ci}\left[{ }^{3} \mathrm{H}\right] \mathrm{UTP}$ (specific activity, $20 \mu \mathrm{Ci} / \mathrm{mmol}$ ). Cyclic AMP was added in various concentrations as given in individual experiments. Reactions were begun with the addition of enzyme. After $4 \mathrm{~min}$ of incubation at $37^{\circ} \mathrm{C}, 4 \mathrm{M}$ ammonium sulfate was added to a final concentration of $60 \mathrm{mM}$ and the incubation continued for $16 \mathrm{~min}$. Reactions were terminated by the addition of $5 \mathrm{ml}$ of $5 \%$ trichloroacetic acid, sodium pyrophosphate. The solutions were passed through nitrocellulose filters (presoaked in $1 \mathrm{mM} \mathrm{ATP}$ ). The filters were washed 2 times with $5 \mathrm{ml}$ of $5 \%$ TCA, 1\% sodium pyrophosphate, dried, and counted for radioactivity in $5 \mathrm{ml}$ of toluene-based scintillation fluid $(4 \mathrm{~g} \mathrm{Omni-}$ fluor $/ 1 \mathrm{~g}$ toluene).

Assay of protein kinase activity. A standard assay

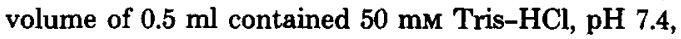
$25 \mathrm{mM} \mathrm{MgCl}_{2}, 1 \mu \mathrm{Ci}\left[\gamma^{32}{ }^{32} \mathrm{P}\right] \mathrm{ATP}$ (specific activity, 16 $\mathrm{Ci} / \mathrm{mmol}$; final concentration, $1.3 \times 10^{-7} \mathrm{M}$ ) and the reactions begun with the addition of enzyme. To measure the magnesium dependence of the reaction, the final concentration of this cation was varied from 5 to $50 \mathrm{~mm}$. Where added, the concentration of EDTA was $50 \mathrm{mM}$. Cyclic AMP was added to some assays in the concentrations given in individual experiments. For measurement of histone phosphorylation, $100 \mu \mathrm{g}$ of lysine-rich histone were added. After $10 \mathrm{~min}$ at $37^{\circ} \mathrm{C}$, $3 \mathrm{ml}$ of $1 \mathrm{~mm}$ ATP were added, followed by $3 \mathrm{ml}$ of 10\% TCA, 2\% sodium pyrophosphate. The samples were filtered through nitrocellulose filters, dried, and counted for ${ }^{32} \mathbf{P}$ in toluene-based scintillation fluid. For precipitation of histone reaction mixtures, $0.002 \mathrm{M}$ silicotungstic acid was added to the $10 \%$ TCA, $2 \%$ sodium pyrophosphate solution.

Protein phosphatase assays. The effect of cyclic AMP on protein phosphatase activity in the soluble nuclear preparation was measured by prephosphorylating these proteins with $\left[\gamma^{-32} \mathrm{P}\right] \mathrm{ATP}$ under standard conditions, followed by the addition of EDTA to the assays to a final concentration of $50 \mathrm{mM}$. These samples were then incubated for an additional $20 \mathrm{~min}$ in the presence or absence of cyclic AMP. These samples were then routinely prepared for electrophoresis, as described below, on 5\% SDS-acrylamide gels.

Electrophoresis of phosphorylated proteins. Protein kinase or protein phosphatase assays were terminated by the addition of solid urea to a final concentration of $4 \mathrm{M}$. The samples were dialyzed against 1 liter of $0.01 \mathrm{~m}$ sodium phosphate, $\mathrm{pH} \mathrm{7.0,0.01 \% 2-}$ mercaptoethanol-0.1\% SDS (dialysis buffer) at room temperature overnight. The samples were then concentrated by dehydration using Bio-gel P-200 and redialyzed. Protein concentration was determined by the method of Lowry (19). Electrophoresis was by the method of Weber and Osborn (20), using 5\% gels. After loading of the gels with protein samples, the gels were run for $4 \mathrm{~h}$ at $8 \mathrm{~mA}$ per gel. Gels were stained in $0.25 \%$ Coomassie blue. After destaining electrophoretically at $200 \mathrm{~mA}$ for $2 \mathrm{~h}$, gels were scanned at $400 \mathrm{~nm}$ in a Gilford spectrophotometer equipped with a linear gel transport device or were sliced at $1-\mathrm{mm}$ intervals and the individual slices counted for ${ }^{32} \mathrm{P}$.

Purification of RNA polymerases and associated proteins by DEAE-Sephadex chromatography. The DEAE-Sephadex used in the column purification was prepared as follows: $10 \mathrm{~g}$ of DEAE-Sephadex (A-25) was swollen overnight in 30 volumes of distilled $\mathrm{H}_{2} \mathrm{O}$ (pH 8.0 with $2 \mathrm{M}$ Tris). The swollen gel was washed two times with 30 volumes $(\mathrm{v} / \mathrm{v}) \quad 0.5 \mathrm{M}$ ammonium sulfate $(\mathrm{pH} 8.0)$ and three times with 30 volumes $(\mathrm{w} / \mathrm{v})$ of the same ammonium sulfate solution. The final washed gel was stored as a suspension in TGMED, $0.05 \mathrm{M}$ ammonium sulfate at $4^{\circ} \mathrm{C}$. Columns of $0.8 \times 12$ $\mathrm{cm}$ were poured and equilibrated under pressure (flow rate, $1 \mathrm{ml}$ per $\mathrm{min}$ ) with 5 bed-volumes of TGMED, $0.05 \mathrm{M}$ ammonium sulfate. Enzyme preparations were applied to the column at this flow rate and the column washed with TGMED, $0.05 \mathrm{M}$ ammonium sulfute until $301-\mathrm{ml}$ fractions had been collected. At this point, a $50-\mathrm{ml}$ linear ammonium sulfate gradient $(0.05$ to $0.5 \mathrm{M}$ ammonium sulfate in TGMED) was started and 1-ml fractions collected.

For RNA polymerase assays, 200 to $500 \mu \mathrm{l}$ of each fraction was employed in the standard RNA polymerase assay described above, except that no additional ammonium sulfate was added to each fraction. Protein kinase assays, as outlined previously, contained 100 $\mu l$ of each column fraction; endogenous protein served as the source of protein kinase activity, as well as substrate in these cases.

Separation of phosphorylated proteins. Column fractionation of phosphorylated proteins was performed after proteins had been labeled with $\left[\gamma^{3}{ }^{32} \mathrm{P}\right]$ ATP in the standard protein kinase assay in the presence or absence of cyclic AMP. Ten identical assays of each type were combined and dialyzed overnight against 1 liter TGMED, $0.05 \mathrm{M}$ ammonium sulfate at $4^{\circ} \mathrm{C}$. The protein was applied to a prepared DEAESephadex column, which was then washed with $30 \mathrm{ml}$ of TGMED, $0.05 \mathrm{M}$ ammonium sulfate, followed by elution of RNA polymerases and associated proteins with a linear gradient $(0.05$ to $0.5 \mathrm{M}$ ammonium sulfate in TGMED). One-tenth milliliter of each fraction was precipitated with $5 \mathrm{ml} 5 \%$ TCA, $1 \%$ sodium pyrophosphate and filtered through nitrocellulose filters and washed two times with $5 \mathrm{ml}$ of the same solution. These filters were then dried and counted in toluenebased scintillation fluid. Column fractions containing peaks of radioactivity were combined and dialyzed against SDS dialysis buffer overnight. They were then concentrated with Bio-gel P-200 and redialyzed prior 
to electrophoresis on $5 \%$ SDS-acrylamide gels by the method of Weber and Osborn (20).

\section{RESULTS}

Characterization of the Protein Kinase Activity Associated with a Soluble Rat Liver Nuclear Preparation

A soluble preparation from rat liver nuclei, prior to chromatography on DEAESephadex, contains appreciable amounts of protein kinase. This unfractionated protein kinase activity catalyzes the phosphorylation of endogenous proteins in the presence of $\left[\gamma^{-}{ }^{32} \mathrm{P}\right] \mathrm{ATP}$ and $\mathrm{Mg}^{2+}$. A minimum of $80 \%$ of the ${ }^{32} \mathrm{P}$-labeling of the proteins within a nuclear extract of this type can be accounted for by $\left[{ }^{32} \mathrm{P}\right]$ phosphoserine (21).

This nuclear protein kinase fraction can also phosphorylate exogenous lysine-rich histone. The magnitude of phosphorylation which occurs when exogenous histone is added to the soluble nuclear preparation is no greater than that seen with endogenous proteins alone (Fig. 1). SDS gel electrophoretic analysis shows that under the former conditions, it is the histones which are phosphorylated, while the incorporation of $\left[\gamma_{-}{ }^{32} \mathrm{P}\right] \mathrm{ATP}$ into the higher molecular weight endogenous proteins is suppressed.
This suggests a possible interaction between these proteins which can influence the ability of some nuclear nonhistone proteins to be phosphorylated.

Although the phosphorylation of both endogenous proteins and lysine-rich histone are dependent upon the presence of $\mathrm{Mg}^{2+}$, the optimal concentration of the cation differs for each substrate. Histones are maximally phosphorylated at approximately $5 \mathrm{mM} \mathrm{Mg}^{2+}$, while endogenous protein phosphorylation by this nuclear protein kinase fraction is supported optimally at a $\mathrm{Mg}^{2+}$ concentration of $25 \mathrm{~mm}$ (Fig. 1). Although the possibility that the ion concentration is affecting the substrates differently cannot be excluded, these $\mathrm{Mg}^{2+}$ concentration curves suggest the presence of at least two distinct protein kinases within the soluble nuclear preparations.

Effects of Cyclic AMP on the Phosphorylation of Histones and of Endogenous Proteins Within the Soluble Nuclear Preparations from Rat Liver

Cyclic AMP, at concentrations from $10^{-5}$ to $10^{-8} \mathrm{M}$, has no apparent effect on the total phosphorylation of either exogenous histones or of endogenous proteins by the

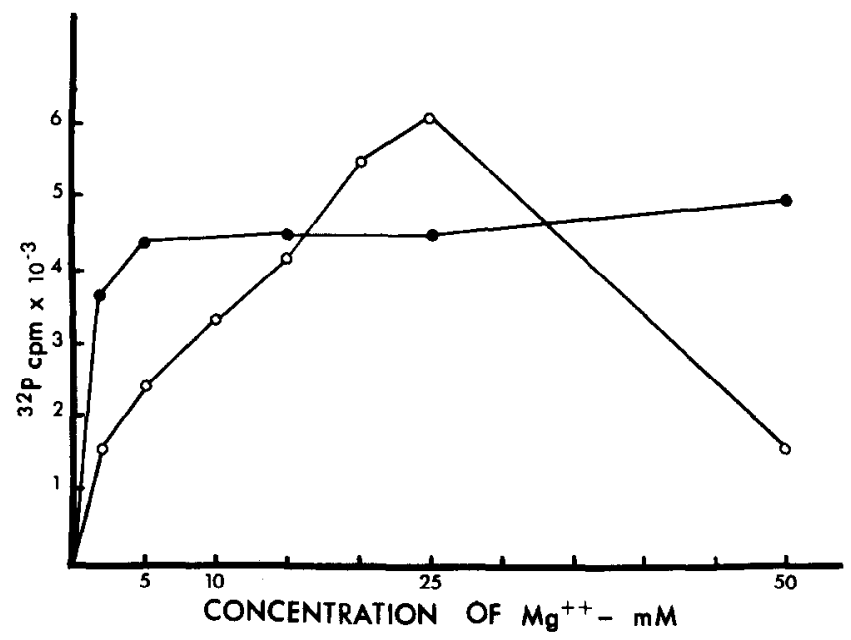

FIG. 1. Magnesium dependence of the protein kinases present in a soluble rat liver nuclear preparation. Rat liver RNA polymerases were prepared by the method of Roeder and Rutter, up to the DEAE-Sephadex chromatography step (18). Aliquots were incubated as described in Materials and Methods for protein kinase activity, except that the magnesium concentration was varied and $100 \mu \mathrm{g}$ of lysine-rich histone were added to some assays. In each case, the reaction volume contained $200 \mu \mathrm{g}$ of enzyme protein. Magnesium dependence of protein kinase without exogenous substrate, $\mathrm{O} O$; magnesium dependence of protein kinase in the presence of lysinerich histone, 
nuclear protein kinase fraction described above (data not shown). Moreover, electrophoresis of lysine-rich histone phosphorylated by this source of nuclear protein kinase shows no detectable differences in the labeling of any individual components of the lysine-rich histone. This lack of response to cyclic AMP is not due to substrate activation of the protein kinase during the time required to set up the assay, as has been reported by Miyamoto, et al. (22), since no effect on phosphorylation of histones is seen regardless of whether the protein kinase reactions were started by addition of labeled ATP or histone (data not shown).

Addition of cyclic AMP to the total soluble nuclear preparation does cause a dramatic reduction in the phosphorylation of a specific Coommasie Blue-staining band, which, because of its migratory behavior (and hence, size) on SDS-acrylamide gels, is a nonhistone. Loss of the ${ }^{32} \mathrm{P}$-labeling of the peak of radioactivity appears to be dependent upon the concentration of cyclic AMP in the phosphorylation medium. Total loss of a specific peak of radioactivity on $5 \%$ SDS-acrylamide gels is seen in the presence of concentrations of cyclic AMP from $10^{-6} \mathrm{M}$ up to $10^{-3} \mathrm{M}$ (Fig. 2, A through E). However, ${ }^{32} \mathrm{P}$-labeling of proteins in the presence of $10^{-7}$ and $10^{-8} \mathrm{M}$ cyclic AMP resembles the control situation, although some reduction in the ${ }^{32} \mathrm{P}$-labeling of this protein band may still be apparent (Fig. 2, $A, F$, and G). To determine whether the decreased ${ }^{32} \mathrm{P}$-labeling seen in the presence of cyclic AMP is caused by inhibition of protein kinase activity, experiments were performed in which soluble nuclear preparations were prelabeled with $\left[\gamma^{32} \mathrm{P}\right]$ ATP. After prelabeling, incubation was continued for an additional $20 \mathrm{~min}$ in the presence of $50 \mathrm{mM}$ EDTA $\pm 10^{-6} \mathrm{M}$ cyclic AMP. (Addition of this concentration of EDTA completely inhibits protein kinase activity, as shown in Fig. 3A).

The ${ }^{32} \mathrm{P}$-labeling of the soluble nuclear fraction remains indistinguishable from control samples, as shown by the solid line in Fig. 3A, after further incubation with EDTA alone. However, since a selective loss of ${ }^{32} \mathrm{P}$-labeling from a specific protein band on SDS gels is seen in the presence of

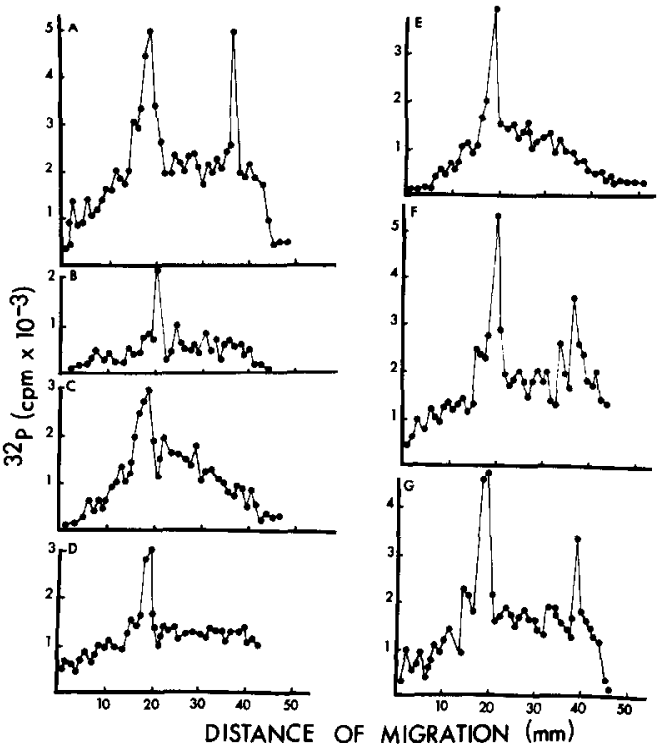

Fic. 2. Effect of cyclic AMP on the phosphorylation of proteins associated with a soluble rat liver nuclear preparation. Standard protein kinase assays were performed with the indicated concentrations of cyclic AMP. Reactions were stopped by the addition of solid urea to a final concentration of $4 \mathrm{M}$. Samples were dialyzed, concentrated, and run on $5 \%$ SDS-acrylamide gels. Gels were sliced, dried, and counted in toluene-based scintillation fluid for ${ }^{32} \mathrm{P}$. A, control; $\mathrm{B}, 10^{-3}$ M cyclic AMP; C, $10^{-4}$ M cyclic AMP; D, $10^{-5}$ M cyclic AMP; E, $10^{-6} \mathrm{M}$ cyclic AMP; F, $10^{-7} \mathrm{M}$ cyclic AMP; G, $10^{-8}$ M cyclic AMP.

$50 \mathrm{mM}$ EDTA and $10^{-6} \mathrm{M}$ cyclic AMP (Fig. $3 B$ ), we conclude that cyclic AMP activates a nuclear protein phosphatase, possessing substrate specificity.

\section{Fractionation of Phosphorylated Proteins on DEAE-Sephadex}

In order to obtain a more defined characterization of the protein component dephosphorylated in response to cyclic AMP, the soluble nuclear preparations were prephosphorylated and the endogenous proteins were separated by DEAE-Sephadex chromatography, employing a 0.05 to $0.5 \mathrm{M}$ ammonium sulfate gradient. After fractionation, phosphorylated proteins appeared in the unbound fraction of the column and were eluted from those regions of the gradient with RNA polymerase activity (Fig. 4). When column fractions were analyzed on 5\% SDS-acrylamide gels, specific pat- 
terns of protein phosphorylation were found in the unbound fraction and in those fractions containing both RNA polymerase I and II (Fig. 5, A, C, and E).

The addition of $10^{-6} \mathrm{M}$ cyclic AMP to the prephosphorylation medium causes no change in the overall distribution of phosphorylated proteins following DEAE-Sephadex chromatography, but does cause a marked inhibition of ${ }^{32} \mathrm{P}$-labeling of one protein component of the unbound fraction (Fig. 5B). Based on its electrophoretic mobility, we assume that the single peak which is less phosphorylated in response to cyclic AMP in the unbound column fraction corresponds, at least in part, to the component dephosphorylated by the cyclic nucleotide in the whole nuclear soluble fraction (com-

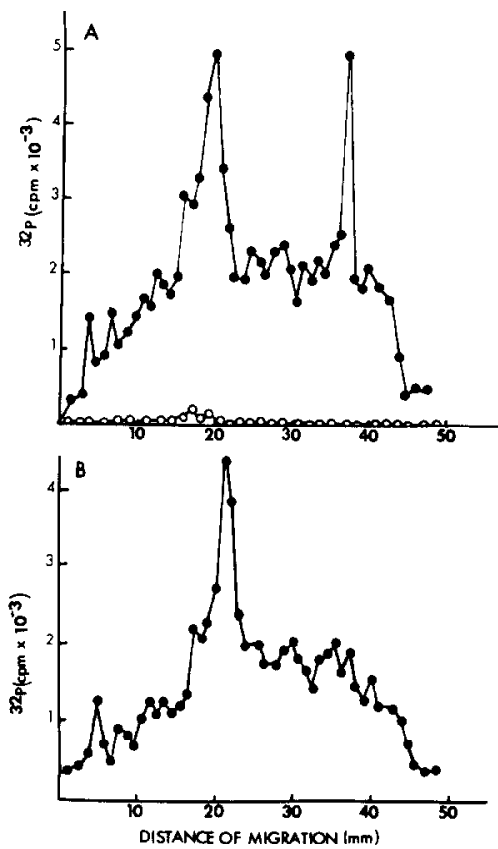

FIG. 3. Effect of cyclic AMP on the protein phosphatase activity associated with a soluble rat liver nuclcar prcparation. $A$, standard protein kinase assays were performed as described in Fig. 2, in the presence or absence of $50 \mathrm{~mm}$ EDTA. $\longrightarrow$, control protein kinase activity; $\mathrm{O}-\mathrm{O}$, protein kinase activity in the presence of $50 \mathrm{mM}$ EDTA. B, standard protein kinase assays were performed. After a 10 -min incubation, 50 mM EDT $\Lambda \pm 10^{-6}$ M cyclic AMP were added and the samples incubated for a further $20 \mathrm{~min}$. Samples were then analyzed by gel electrophoresis as described in Materials and Methods. pare Fig. 3A with Fig. 5A). Changes in the phosphorylation pattern of the proteins in the RNA polymerase I column fractions are also seen in the presence of $10^{-6} \mathrm{M}$ cyclic AMP (Fig. 5D), although the absolute changes in the peaks of radioactivity relative to one another have not yet been determined.

The presence of a single, phosphorylated protein in RNA polymerase II column fractions (Fig. 5E) makes determination of the effect of cyclic AMP on its labeling difficult. However, as shown by data in the following section, cyclic AMP inhibits the protein kinase activity associated with RNA polymerase II on a DEAE-Sephadex column, using endogenous proteins as substrates. Since electrophoretic analysis demonstrates only a single phosphorylated protein within this fraction, it follows logically that cyclic AMP must be causing reduction in the ${ }^{32} \mathrm{P}$-labeling of this protein.

To ease description of the data, we have devised a nomenclature for the phosphorylated proteins derived by fractionation of the soluble rat liver preparation on DEAESephadex. The protein component found in the unbound fraction is termed cyclic AMP-influenced protein I, or simply, CAI. The single, phosphorylated protein cochromatographing with RNA polymerase II is called cyclic AMP-influenced protein II (CAII). These proteins are designated as such in Fig. 5, B and F.

\section{Molecular Weight Estimates of CAI and CAII}

Molecular weights of CAI and CAII were estimated by comparison to proteins of known molecular weights derived from red blood cell membranes (23). Samples run on $5 \%$ SDS-acrylamide gels indicate the size of protein CAI to be 28,000 and of protein CAII to be 52,000 . The reported molecular weights of $197,000,126,000,51,000,44,000$, 25,000 and 16,500 for the subunits of liver RNA polymerase I (24) and 220,000, $214,000,180,000,165,000,140,000,34,000$, 25,000 , and 16,500 for a mixture of the subunits of the two forms of liver RNA polymerase II (25) suggest that CAI and CAII are not RNA polymerase subunits (Fig. 6). This is further suggested in the case of CAI by 


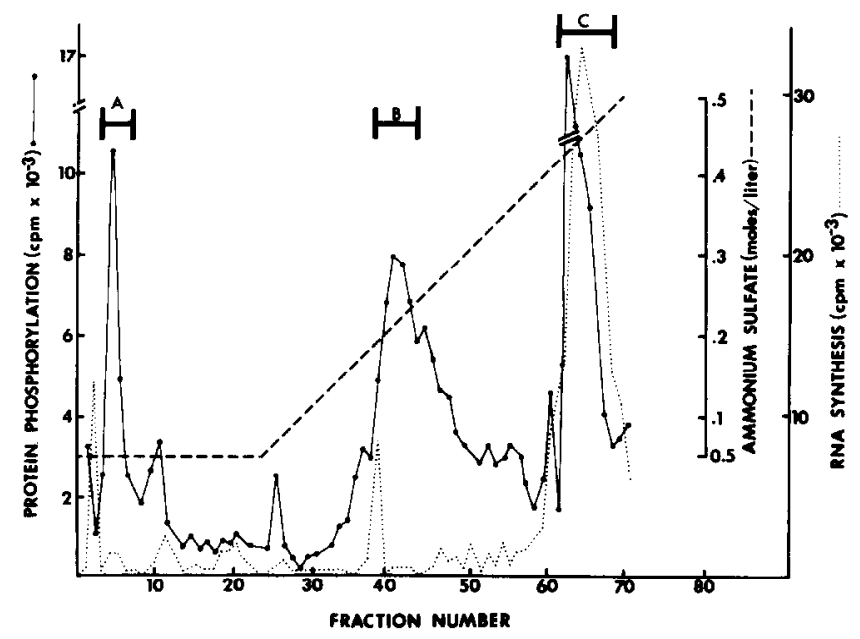

Fig. 4. Fractionation of ${ }^{32} \mathrm{P}$-labeled soluble nuclear preparation from rat liver on DEAESephadex. Proteins were prelabeled in a standard protein kinase reaction, dialyzed against TGMED, $0.05 \mathrm{M}$ ammonium sulfate at $4^{\circ} \mathrm{C}$, and chromatographed as described in Materials and Methods. An aliquot of each column fraction was assayed for RNA polymerase activity and counted for ${ }^{32} \mathrm{P}$ in toluene-based scintillation fluid.

the fact that this protein separates from the RNA polymerases on DEAE-Sephadex.

\section{Effects of Cyclic AMP on Protein Kinase Activities Associated with DEAE-Seph- adex Column Fractions}

After chromatography of the soluble preparation from rat liver nuclei on DEAESephadex, protein kinase activity is found associated with the unbound fraction and also in those fractions possessing RNA polymerase I and II activities. Moreover, these protein kinases demonstrate markedly different responses to $10^{-6} \mathrm{M}$ cyclic AMP. The protein kinase in the unbound fraction is stimulated by the cyclic nucleotide, whereas protein kinase activities cochromatographing with RNA polymerase I and II are dramatically inhibited by the same concentration of cyclic AMP (Table I). It should be noted that the DEAE-Sephadex fractions served as the source of both protein kinase and substrate for the phosphorylation.

The possibility exists that the action of cyclic AMP on RNA polymerase I and II column fractions is the activation of endogenous protein phosphatases, rather than the inhibition of protein kinase activities within these fractions. We find this unlikely, however, because we find no signifi- cant protein phosphatase activity associated with RNA polymerase I or II fractions, using ${ }^{32} \mathrm{P}$-labeled nuclear phosphoproteins as substrates, in either the presence or absence of $10^{-6} \mathrm{M}$ cyclic AMP.

Under these conditions, protein phosphatase activity is found only in the unbound fraction following DEAE-Sephadex chromatography. A slight stimulation (approximately $20 \%$ ) of this enzyme activity is seen in response to $10^{-6} \mathrm{M}$ cyclic AMP. This small degree of cyclic AMP-dependent activation may reflect the use of an exogenous, heterogeneous substrate. Alternately, DEAE-Sephadex chromatography may cause a separation of this protein phosphatase activity from a regulatory factor which normally confers a cyclic AMP-dependence upon this enzyme.

Reconstitution of DEAE-Sephadex Unbound Fraction and RNA Polymerase II Column Fractions

Factors influencing the activity of eukaryotic RNA polymerases have been described $(26,27)$ and some indications exist that these may be phosphorylated proteins $(28,29)$. Therefore, we sought to determine whether the phosphorylated proteins we have identified could modify the activity of RNA polymerase. 

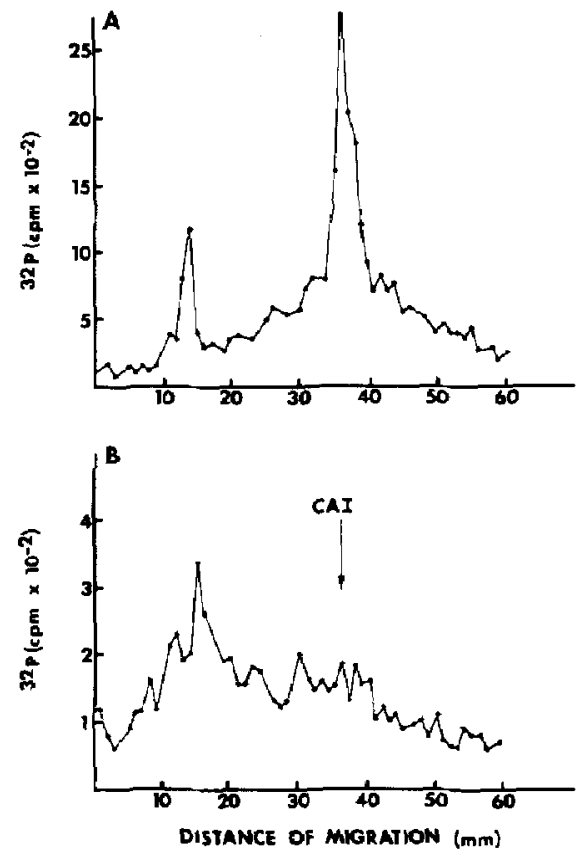
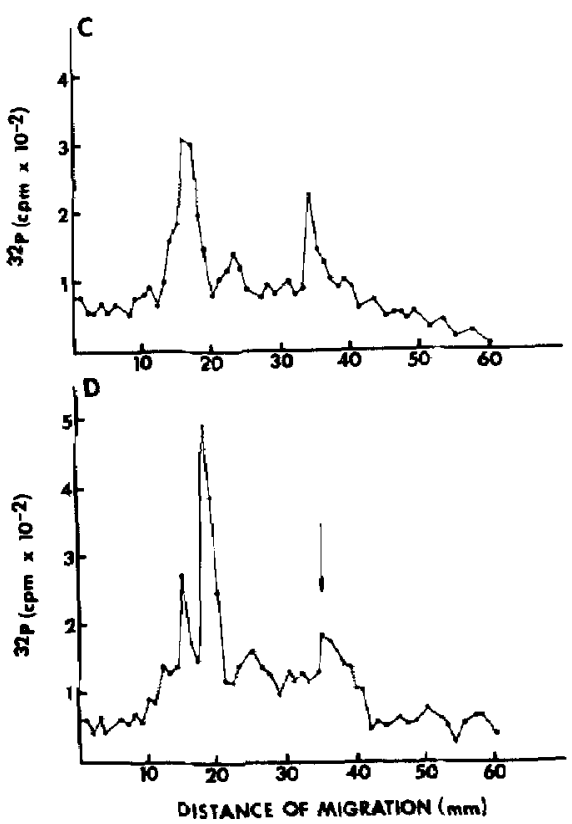

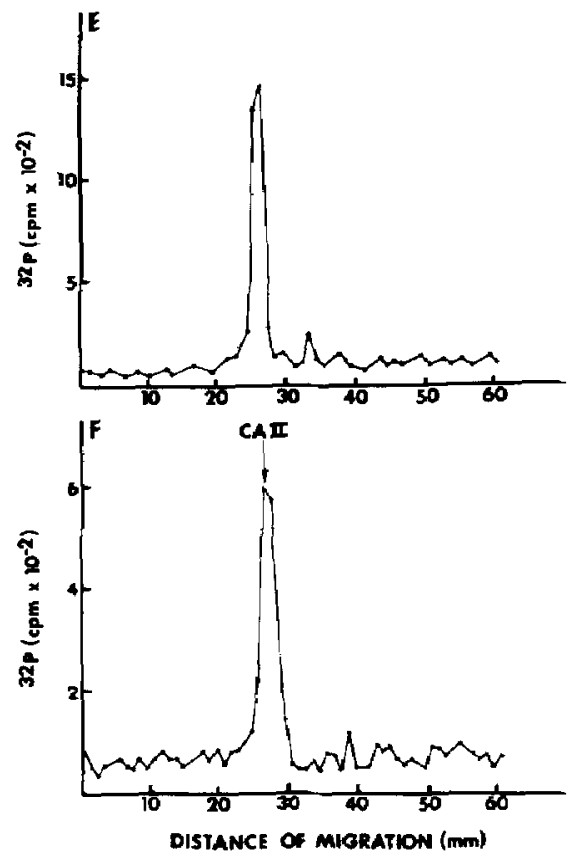

FIG. 5. Effect of cyclic AMP on the labeling of proteins associated with rat liver RNA polymerase after DEAE-Sephadex chromatography. Soluble rat liver nuclear preparations were prephosphorylated in a standard protein kinase reaction $\pm 10^{-6} \mathrm{M}$ cyclic AMP as described in Materials and Methods and fractionated on a DEAE-Sephadex column. In each case, the peaks of ${ }^{32}$ P-labeled material were collected as indicated by the bracketed areas in Fig. 4 and termed the unbound fraction (A), RNA polymerase I (B), and RNA polymerase $\square$ (C) fractions. Each was analyzed on 5\% SDS-acrylumide gels. A, control-unbound fraction; B, cyclic AMP-unbound fraction; $C$, controlRNA polymerase I fraction; D, cyclic AMP-RNA polymerase I fraction; E, control-RNA polymerase II fraction; F, cyclic AMP-RNA polymerase II fraction. 


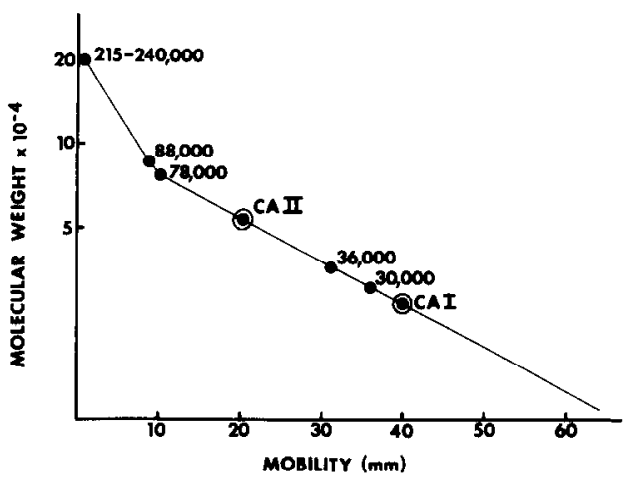

FIG. 6. Determination of the molecular weight of CAI and CAII by SDS acrylamide electrophoresis. Proteins of known molecular weight, derived from red blood cell membranes, were used as markers for the estimation of the molecular weights given in the figure. Marker proteins, CAI and CAII were run on 5\% SDSacrylamide gels as described in Materials and Methods.

TABLE I

Effect of Cyclic AMP on Protein Kinase Activities Associated with Rat Liver RNA Polymerase Column Fractions ${ }^{a}$

\begin{tabular}{lc}
\hline \multicolumn{1}{c}{ Column fraction } & $\begin{array}{c}\text { Protein kinase } \\
\text { activity } \\
\left({ }^{32} \mathrm{P} \mathrm{cpm}\right)\end{array}$ \\
\hline Unbound fraction, control & 280 \\
Unbound fraction, cyclic AMP & 1325 \\
RNA polymerase I, control & 928 \\
RNA polymerase I, cyclic AMP & 88 \\
RNA polymerase II, control & 961 \\
RNA polymerase II, cyclic AMP & 153 \\
\hline
\end{tabular}

${ }^{a}$ Rat liver RNA polymerases were fractionated on a DEAE-Sephadex column and the unbound fraction, RNA polymerase I and II fractions collected. Endogenous protein kinase activity of these fractions was measured in a standard protein kinase assay in the presence or absence of $10^{-6} \mathrm{M}$ cyclic AMP. Amounts of protein in the protein kinase assays equal $50 \mu \mathrm{g}$ for the unbound and RNA polymerase I fractions and $100 \mu \mathrm{g}$ for the RNA polymerase II fractions.

As one approach, the following recombination experiments were performed. Soluble rat liver nuclear preparations were prephosphorylated with unlabeled ATP in the presence or absence of $10^{-6} \mathrm{M}$ cyclic AMP. These reaction volumes were dialyzed overnight against TGMED, $0.05 \mathrm{M}$ ammonium sulfate, and in each case, the CAI-containing fraction was purified by DEAE-Sephadex chromatography. These CAI fractions were then added separately to column-pu-
TABLE II

Effect of CAI on the Activity of PuRIfied RNA POLYMERASE II FROM RAT LIVER

\begin{tabular}{lc}
\hline \multicolumn{1}{c}{ Incubation condition } & $\begin{array}{c}\text { RNA } \\
\text { polymerase } \\
\text { activity } \\
\left({ }^{3} \mathrm{H} \mathrm{cpm}\right)\end{array}$ \\
\hline RNA polymerase II & 2152 \\
RNA polymerase II + CAI & 2430 \\
RNA polymerase II + CAI (preincu- & 367 \\
bated with $10^{-6} \mathrm{M}$ cyclic AMP) &
\end{tabular}

${ }^{a}$ CAI (100 $\mu$ ), purified by DEAE-Sephadex chromatography after preincubation in the presence or absence of $10^{-6} \mathrm{M}$ cyclic AMP, was added to $200 \mu \mathrm{g}$ of column-purified RNA polymerase II. RNA polymerase activity was determined by the standard reaction.

rified RNA polymerase II preparations. Table II demonstrates that CAI, preincubated in the absence of cyclic AMP, has no effect on RNA polymerase II activity. However, if CAI is purified after preincubation with $10^{-6} \mathrm{M}$ cyclic AMP and then added to RNA polymerase II, it has acquired the ability to inhibit RNA synthesis. Since the dephosphorylation of CAI is the only apparent effect of cyclic AMP on the components of the unbound column fraction, it is assumed that it is this modification which is correlated with the ability of this column fraction to inhibit the activity of RNA polymerase II.

\section{DISCUSSION}

Information accumulating on the involvement of cyclic AMP in the regulation of nuclear function demonstrates that this nucleotide can act in a variety of ways to modify the phosphorylated state of certain nuclear proteins. Our work reinforces these observations and provides the added information that cyclic AMP-induced modifications of nuclear protein phosphorylation may result from alterations in the activity of both phosphoprotein kinases and phosphatases. More specifically, we have demonstrated, in a system derived from rat liver nuclei, that cyclic AMP can 1) inhibit those forms of nuclear protein kinase which cochromatograph on DEAE-Sephadex with both RNA polymerase I and II; 2) stimulate the protein kinase which separates from these RNA polymerases on the same column; and 3) activate a nuclear protein phos- 
phatase with apparent substrate specificity. In addition, we have identified two specific nuclear proteins whose state of phosphorylation appears to be influenced by cyclic AMP, suggesting their possible identity as functional substrates for the enzymes described above.

Kish and Kleinsmith (15) have shown heterogeniety within the class of nuclear protein kinases which phosphorylate nonhistone proteins, both with regard to substrate specificity and response to cyclic AMP. Our work provides further data with regard to these characteristics by analyzing nuclear protein kinase and phosphatase activities in association with endogenous substrates, rather than relying on measurement of the ${ }^{32} \mathrm{P}$-labeling of exogenously added proteins by these enzymes. Such an approach may allow a more functional characterization of the phosphorylation of specific nuclear proteins.

DEAE-Sephadex chromatography of rat liver RNA polymerases results in a concommitant separation of several peaks of protein kinase activity. Although each peak may contain multiple species of protein kinase, a predominant response to cyclic AMP is seen in each case. The unbound protein kinase is stimulated by cyclic AMP, producing enhanced labeling of endogenous protein(s). This enzyme fraction is probably identical to that reported by Jungmann and Kranias (30). The protein kinase activities co-chromatographing with RNA polymerases I and II are markedly inhibited by the cyclic nucleotide, using endogenous proteins as substrates. The enhanced activity of the unbound protein kinase may be an example of the classic mechanism of cyclic AMP-dependent protein kinase activation. However, the means by which this cyclic nucleotide inhibits some forms of protein kinase activity, such as those described here, remains entirely unknown.

Although a cyclic AMP-dependent protein phosphatase has been described for membrane preparations (31), our work provides the first example of a nuclear protein phosphatase which seems to be under the regulation of cyclic AMP. Furthermore, this particular phosphoprotein phosphatase possesses a degree of substrate specificity which implies the partial characterization of the endogenous substrate for this enzyme, a protein which we have termed CAI.

The activation of CAI-specific phosphatase by cyclic AMP takes place even when protein kinase activity is inhibited by a high concentration of EDTA. Under these conditions, phosphorylation of CAI-phosphatase is eliminated as a mechanism of activation. In this regard, CAI-phosphatase resembles the membrane-bound phosphatase described by Maeno et al. (31) in its ability to be stimulated by cyclic AMP in the absence of protein kinase activity. The possibility is not ruled out, however, that cyclic AMP stimulates this protein phosphatase by dissociating a catalytic activity from an inhibitory regulatory component, in a manner analogous to the situation which exists for cyclic AMP-dependent protein kinases.

Supportive evidence for the idea that nuclear protein kinase and protein phosphatase activities may exist in functional association within the chromatin already exists. Johnson et al. (32) state that the catalytic subunit of a cyclic AMP-dependent nuclear protein kinase from calf thymus binds directly to DNA, possibly indicating a means by which sites of phosphorylation are specified within the chromatin. Bombik and Baserga (33) have described a stimulation of chromatin-bound protein kinase during proliferation of WI-38 fibroblasts which can be blocked by dibutyryl cyclic AMP. A functional complex of protein kinase and protein phosphatase has been located within synaptosomal membranes from cerebral cortex (34), and further experimentation may show a similar association of enzyme activities within the nucleus, providing a mechanism by which the phosphorylation of regulatory proteins may be reversibly modified.

On the basis of our findings, we can identify two specific nuclear proteins whose phosphorylated states appear to be influenced by cyclic AMP. Both proteins are dephosphorylated in response to cyclic AMP, but the mechanisms by which cyclic AMP causes dephosphorylation of each differs. In one case, CAI, dephosphorylation is achieved by the activation of a cyclic AMPdependent protein phosphatase, while in 
the other, CAII, it is achieved by inhibition of protein kinase activity.

After preincubation with cyclic AMP, CAI inhibits RNA polymerase activity when added to column-purified RNA polymerase II. If CAI has not been preincubated with cyclic AMP, it has no apparent effect on RNA polymerase II activity. Thus, since electrophoretic analysis demonstrates that cyclic AMP is influencing the phosphorylated state of CAI, we assume it is this modification which determines the ability of CAI to alter the activity of RNA polymerase II. Although these results are of a preliminary nature, the dependence upon the dephosphorylated state of CAI to produce inhibition of RNA polymerase II suggests some degree of specificity in the response. A number of reports in the literature discuss the possibility of phosphorylation as a regulatory mechanism in determining the activity of protein factors associated with RNA polymerase and seem consistent with our findings.

For example, Natori et al. (26) have described a nuclear protein factor (SII) which interacts with RNA polymerase II. Although this SII stimulates, rather than inhibits RNA polymerase II activity, it shares some characteristics with our CAI. Both are found in the unbound fraction of the DEAE-Sephadex column used to separate RNA polymerases. Moreover, dephosphorylation of both proteins produces negative effects on RNA polymerase activity. Incubation with alkaline phosphatase destroys the ability of SII to stimulate RNA polymerase II (28), while dephosphorylation by a cyclic AMP-dependent phosphatase appears to allow CAI to inhibit the activity of RNA polymerase II. However, the identity of dephosphorylated CAI as an "RNA synthesis factor" requires more detailed analysis of the mechanism by which it produces inhibition of RNA polymerase II activity.

Our data also provide some suggestions that CAII may be involved in the regulation of RNA polymerase activity. Although not a RNA polymerase subunit, it co-chromatographs with RNA polymerase II on a DEAE-Sephadex column, and can be phosphorylated by an endogenous protein kinase within this fraction. Cyclic AMP causes a dephosphorylation of CAII through inhibition of this protein kinase. Johnson and Hadden (16) have described a lymphocyte nuclear acidic protein of identical molecular weight $(52,000)$ whose phosphorylation is decreased by agents which elevate cellular cyclic AMP levels. Furthermore, they can correlate these changes with inhibition of the incorporation of $\left[{ }^{3} \mathrm{H}\right]$ uridine into RNA. Thus, CAII may be a nuclear protein distributed among a variety of tissues and involved in the regulation of chromatin RNA synthesis.

Recent reports have appeared suggesting phosphorylation of RNA polymerase itself stimulates the activity of this enzyme. Martelo and Hirsch (35) have phosphorylated rat liver RNA polymerase with nuclear protein kinase and have shown stimulatory effects on enzyme activity. Although cyclic AMP, in their system, does stimulate protein kinase activity using RNA polymerase as substrate, it has little effect on simultaneous RNA synthesis by RNA polymerase II. Jungmann et al. (36) have looked at RNA polymerase phosphorylation in a more homologous system. Using ovarian cytosol protein kinase which had been dissociated to a cyclic AMP-independent form to phosphorylate RNA polymerase II from the same tissue, they have shown subsequent positive effects on RNA polymerase II activity. However, they have not dismissed the possibility that it is the phosphorylation of RNA polymerase-associated proteins which are being affected by cyclic AMP, and their results could be explained by a system of regulation involving the interaction of a CAI-type protein with RNA polymerase II. Likewise, Dahmus (29) has shown that ascites RNA polymerase II activity is stimulated by a protein factor (HLF2) which has protein kinase activity. Although highly purified RNA polymerase II seems to be directly phosphorylated in this system, the possibility has not been eliminated that it is the phosphorylated state of HLF2, or a protein associated with either HLF2 or RNA polymerase II which is functionally correlated with the stimulation of RNA polymerase II.

We wish to suggest that the various effects of cyclic AMP within the nucleus on protein phosphorylation may be correlated to modifications of protein kinase and phos- 
phatase activities. Whether the resulting alterations in protein phosphorylation serve a regulatory function in determining specific patterns of RNA synthesis in vivo and in vitro is a question deserving of further study. It is worth pointing out in this regard that recent evidence suggests that phosphorylation of nonhistone proteins selectively influences the rate of histone gene transcription (37), although this effect has not yet been linked to changes in cyclic AMP.

\section{ACKNOWLEDGMENTS}

The authors are grateful to Kathy Leonardson, who performed the protein phosphatase assays on DEAESephadex column fractions, and to Dr. Valerie Kish, for the gift of red blood cell membrane proteins. This work was supported by Grants BMS 74-23418 and PCM 77-23789 from the National Science Foundation.

\section{REFERENCES}

1. Huang, H-C. C., and Bonner, J. (1962) Proc. Nat. Acad. Sci. USA 48, 1216-1222.

2. Allfrey, V. G., Littad, V. C., ANd Mirsky, A. E. (1963) Proc. Nat. Acad. Sci. USA 49, 414-421.

3. Stellwagon, R. H., and Cole, R. D. (1969) Annu. Rev. Biochem. 38, 951-990.

4. Kleinsmith, L. J. (1975a) J. Cell Physiol. 85, 459-476.

5. Platiz, R. D., Kish, V. M., and Kleinsmith, L. J. (1970) FEBS Lett. 12, 38-40.

6. PAUl, J., AND GILMOUR, R. J. (1968) J. Mol. Biol. 34, 305-316.

7. Spelsberg, T. C., Hnilica, L. S., ANd Ansevin, A. T. (1971) Biochim. Biophys. Acta 228, 550-562.

8. Davidson, E. H., and Britten, R. J. (1974) Q. Rev. Biol. 48, 565-613.

9. LANGan, T. A. (1967) in Regulation of Nucleic Acid and Protein Synthesis, BBA Library Series (Koningsberger, V. V., and Bosch, C., eds.), pp. 233-242, American Elsevier, New York.

10. Gottesfield, J. M., Calvin, M., Cole, R. D., IgDaloff, D. M., Moses, V., AND VAUghN, W. (1972) Biochemistry 11, 1422-1430.

11. Stein, G. S., Spelsberg, T. C., and Kleinsmith, L. J. (1974) Science 183, 817-824.

12. Kleinsmith, L. J. (1975b) in Chromosomal Proteins and Their Role in the Regulation of Genetic Expression (Stein, G. S., and Kleinsmith, L. J., eds.), pp. 45-57, Academic Press, New York.

13. LaNGan, T. A. (1970) in Role of Cyclic AMP in Cell Function (Greengard, P., and Costa, E., eds.), pp. 307-323, Raven Press, New York.

14. Johnson, E. M., AND ALlfrey, V. G. (1972) Arch. Biochem. Biophys. 157, 786-794.

15. Kish, V. M., AND KLEINSmith, L. J. (1974) $J$. Biol. Chem. 249, 750-760.

16. Johnson, E. M., and Hadden, J. W. (1975) Science 187, 1198-1200.

17. Dokas, L. A., Rittschof, D., and Kleinsmith, L. J. (1975) Adv. Cyclic Nucl. Res. 5, 828.

18. Roeder, R. G., ANd Rutter, W. J. (1970) Proc. Nat. Acad. Sci. UTSA 65, 675-682.

19. LoWry, O. J., Rosebrough, N. T., FARR, A. C., and Randall, R. J. (1951) J. Biol. Chem. 193, 265-275.

20. Weber, K., ANd Osborn, M. (1969) J. Biol. Chem. 244, 4406-4412.

21. KLeinsmith, L. J., Allfrey, V. G., AND Mirsky, A. E. (1966) Proc. Nat. Acad. Sci. USA 55, 1182-1189.

22. Miyamoto, E., Petzold, G. L., Kuo, J. K., And GreEngard, P. (1971) Biochem. Biophys. Res. Commun. 44, 305-312.

23. STECK, T. (1974) J. Cell Biol. 62, 1-31.

24. Chambon, P. (1975) in Annual Review of Biochemistry (Snell, E. E., ed.), pp. 613-638, Annual Reviews, Inc., Palo Alto, California.

25. Chambon, P., Gissinger, F., Kedinger, C., ManDEL, J. L., AND MeILhac, M. (1974) in The Cell Nucleus (Busch, H., ed.), Vol. 3, pp. 270-308, Academic Press, New York.

26. Natori, S., TAKeuChi, K., AND Mizuno, D. (1973) J. Biochem. 73, 879-888.

27. Lee, S. G., and Dahmus, M. (1973) Proc. Nat. Acad. Sci. USA 70, 1381-1387.

28. Natori, S., Sekimizu, T., ANd Mizuno, D. (1974) J. Biochem. 76, 695-702.

29. Dahmus, M. (1976) Biochemistry 15, 1821-1829.

30. JungmanN, R. A., AND KRanias, E. G. (1976) in Advances in Biochemical Pharmacology (Costa, E., Giagolini, E., and Paoletti, R., eds.), Vol. 15, pp. 413-428, Raven Press, New York.

31. Maeno, H., Ueda, T., and Greengard, P. (1975) J. Cyclic Nucl. Res. 1, 37-48.

32. Johnson, E. M., Hadden, J. W., Inoue, A., AND AllfREY, V. G. (1975) Biochemistry 14, 3873-3883.

33. Bombik, B., AND Barserga, R. (1976) Biochim. Biophys. Acta 442, 343-357.

34. Ueda, T., Rudolph, S., and Greengard, P. (1975) Arch. Biochem. Biophys. 170, 492-503.

35. Martelo, O. T., ANd Hirsch, J. (1974) Biochem. Biophys. Res. Commun. 58, 1008-1015.

36. Jungmann, R. A., Hiestand, P. C., and SCHWEppe, J. S. (1974) J. Biol. Chem. 249, 5444-5451.

37. Kleinsmith, L. J., Stein, J., ANd Stein, G. (1976) Proc. Nat. Acad. Sci. USA 73, 1174-1178. 